\title{
Bushido dalam Masyarakat Jepang Modern
}

\author{
Bambang Wibawarta
}

\begin{abstract}
Bushido is most often translated as the way of the warrior caste in Japan. Bushi refers to warriors in feudal Japan while do means several things including: the correct way, the path, or the road. Another interpretation of Bushido could be the way of preserving peace through the use of force. Bushido comes out of Buddhism, Confucianism, and Shintoism. The combination of these schools of thought and religions has formed the code of warrior values known as Bushido. A key to our understanding of how the concepts of Bushido fit into Japanese modern lives is to understand the historical and societal aspects of Bushido. Today, this meaning can be modernized to include minimizing violent conflict. The code of Bushido, the Samurai's code of honor, upholds loyalty, discipline, total dedication, honor and valor, and numerous examples of these elements can be witnessed today or in recent history.
\end{abstract}

KEYWORDS Bushido, samurai, Japanese ethic.

Jepang memiliki posisi yang sangat penting dalam perekonomian global dewasa ini. Tentu saja hal ini tidak merupakan suatu hal yang terjadi begitu saja, tetapi melalui proses panjang. Untuk dapat memahami dengan baik Jepang dewasa ini, kiranya perlu menelusuri kembali proses yang telah dilalui bangsa Jepang. Selain itu, perlu memahami pula nilai-nilai yang ada dalam masyarakat Jepang yang tidak terkikis oleh derasnya arus modernisasi.

Dalam makalah ini akan diuraikan sebagian dari latar belakang tersebut di atas. Dengan demikian, kita dapat belajar dari apa yang telah dilakukan Jepang. Jepang dapat mengejar ketinggalan mereka dari bangsa Barat karena memiliki keinginan belajar dan dapat memanfaatkan suatu momentum untuk kepentingan mereka (negara). Tidak hanya peristiwa-peristiwa seperti Restorasi Meiji (1868), tetapi juga bencana seperti gempa bumi dahsyat Kanto (1923) serta pengeboman Hiroshima dan Nagasaki (1945) dapat dimanfaatkan sebagai suatu hal positif dan dijadikan suatu pelajaran dan momentum untuk menjadi lebih baik. Kata belajar mengungkap konsep yang sangat penting untuk mencapai suatu kemajuan. Belajar dalam bahasa Jepang diekspresikan dengan kata manabu, atau manebu, atau dalam bahasa Jepang klasik disebut juga sebagai maneru. Istilah maneru ini dapat diterjemahkan ke dalam bahasa Indonesia sebagai meniru. Jadi, belajar itu dimulai dari meniru. Inilah yang dilakukan Jepang pada awalnya, yaitu meniru negara-negara yang sudah 
maju sebelum mereka. Tidak terkecuali dalam bidang teknologi, pada awalnya mereka meniru, kemudian memodifikasinya, dan menjadikannya milik mereka sendiri.

Dalam proses belajar dan meniru tersebut, bangsa Jepang tidak lupa akan identitas dan nilai-nilai yang telah lama melekat dalam diri mereka. Kita dapat melihat Jepang modern yang secara sadar masih memelihara nilai-nilai tradisional tersebut dengan baik. Hal ini sangat penting artinya untuk menciptakan keseimbangan dan dijadikan tempat berpegang dalam perubahan yang terus bergulir. Salah satu nilai yang sering dianggap masih melekat dalam diri bangsa Jepang adalah nilai-nilai bushido.

\section{Metode Penelitian}

Dalam menyusun tulisan ini, peneliti melakukan penelitian kepustakaan. Metode penelitian yang dipergunakan adalah metode penelitian kualitatif. Metode ini mencakup makna dan proses yang cukup luas. Dari segi makna, penelitian kepustakaan mempunyai arti sebagai penelitian yang tidak menggunakan angka dalam pengumpulan data dan secara proses melibatkan berbagai pendekatan. Dalam penelitian kepustakaan, pertama-tama dilakukan pengumpulan data. Data yang diperoleh, kemudian, diinventarisasikan dan dianalisis, untuk selanjutnya disimpulkan.

\section{Sistem Stratifikasi Sosial, Bushido, Dan Jalan Samurai}

Menjelang abad ke-10, para tuan tanah yang pada umumnya tinggal di ibu kota mulai mempersenjatai kaum petani dan berusaha meningkatkan ilmu kemiliteran, seperti memanah, berkuda, dan menggunakan pedang serta tombak. Semakin lama kelompok bersenjata ini semakin kuat dan jumlahnya bertambah besar. Mereka dipimpin oleh para mantan bangsawan dari keluarga Taira dan Minamoto. Bahkan, para petugas pemungut pajak pemerintah tidak berdaya menghadapi mereka. Lama-kelamaan ibu kota Heian (Nara) juga menjadi tidak aman. Keluarga penguasa menggunakan orang bersenjata, atau yang lebih dikenal dengan bushi atau samurai, untuk melindungi harta benda mereka. Di sisi lain, kelompok orang bersenjata ini muncul akibat ketidakberdayaan pasukan keamanan pemerintah dalam menghadapi gerombolan pengacau. Selanjutnya, kelompok kecil samurai bergabung dengan kelompok yang lebih besar sehingga kekuatan samurai menjadi semakin menonjol.

Pada zaman Edo (1603-1867) terdapat sistem stratifikasi sosial (mibun seido) yang membagi masyarakat Jepang dalam empat tingkatan, yang disebut shinokosho. Shi merupakan singkatan dari bushi (kaum samurai atau prajurit), no dari nomin (petani), ko dari kosakunin (perajin), dan sho dari shonin (pedagang). Sistem penggolongan tersebut mengatur dengan ketat status dan peran dari tiap-tiap golongan. Seseorang yang telah dilahirkan dalam golongan tertentu tidak dapat naik ke kelas lain begitu saja. Tiap-tiap kelas tersebut dibedakan menurut pekerjaan atau cara mereka untuk hidup. Nilai pekerjaan yang 
menentukan status seseorang tersebut diukur menurut beban tanggung jawab secara ekonomis dan pengorbanannya bagi kaum penguasa. Dengan demikian, hal itu berarti menempatkan suatu kelas pada tingkat yang lebih tinggi jika ia bekerja lebih keras atau lebih banyak berguna bagi kepentingan kaum penguasa dengan keuntungan yang lebih kecil bagi dirinya sendiri.

Berdasarkan sistem tersebut, kaum samurai (bushi) menduduki posisi paling tinggi karena memegang tampuk kekuasaan. Sebagai kelas penguasa, jalan hidup serta tingkah laku bushi menjadi cerminan yang mewakili kehidupan masyarakat feodal yang berpusat pada pola shuju kankei, atau hubungan atasan-bawahan (majikan-bawahan). Dalam pola ini terkandung ajaran tingkah laku yang di antaranya adalah penghormatan terhadap atasan, keberanian berkorban, balas budi, dan kesungguhan. Semua ini juga tercermin pada tingkah laku bushi di medan perang yang berusaha mengejar nama baik dan harga diri dan berani berkorban demi tugas.

Kaum petani (nomin) ditempatkan setelah bushi karena mereka bekerja sepanjang tahun dan mencurahkan segenap tenaganya untuk menghasilkan sesuatu bagi kepentingan atau untuk dikonsumsi kaum penguasa. Adapun kontribusi para perajin (kosakunin) dianggap lebih kecil daripada petani, dan shonin dianggap lebih banyak mengeruk keuntungan bagi diri mereka sendiri.

Shinokosho dapat diartikan sebagai pemisahan atau pembagian kerja. Tiap-tiap kelas sosial memiliki pandangan yang harus direalisasikan dalam tindakan yang sesuai dengan status sosial yang mereka miliki. Secara garis besar, penggolongan ini membedakan antara tindakan bushi dan tindakan tiga kelas lainnya dari segi moral feodal. Kelas no-ko-sho yang bergerak dalam kegiatan ekonomis secara langsung dianggap berada di luar kehidupan moral, sedangkan bushi dianggap berada pada posisi yang memberikan aturan moral kepada tiga lapisan masyarakat lainnya.

Istilah Bushido berasal dari kata bushi di atas. Meskipun kerap dibicarakan bahwa Jepang memiliki semangat Bushido, sebenarnya tiap-tiap strata memiliki pemikiran dan ajaran tersendiri yang mereka jadikan pedoman dalam berperilaku. Misalnya, kaum pedagang memiliki moralitas untuk selalu menekankan humanisme, objektivitas, dan rasionalitas, di samping tentu saja terpengaruh oleh suasana kehidupan feodal dalam pembentukan akal budi mereka. Hasil dari proses tersebut akhirnya membentuk aturan dalam bertingkah laku yang sesuai dengan akal budi tadi, yang kemudian disebut sebagai etika atau etos kerja. Secara umum etika tersebut tercermin dalam ajaran dan pemikiran yang mengandung etika yang berkembang pada masa itu, dan biasanya tersisa dengan jelas atau bahkan berkembang pada masa selanjutnya. Yuasa Yasuo dalam Keizai jin no Moral (1967) menyatakan bahwa pada zaman Meiji berkembang moralitas yang berhubungan dengan masalah ekonomis, yakni moral atau etika jiritsu jiei (mandiri), shoujiki (jujur), kimben (rajin), kenyaku (hemat), jizen ( amal), koueki (untuk kepentingan umum). Kecuali Koueki, etika tersebut sudah ada sejak zaman Edo. Shoujiki dan jizen dapat dikatakan sebagai aspek humanitas, sedangkan etika kenyaku merupakan aspek rasionalitas. 
Sistem pemerintahan feodal di Jepang berlangsung selama hampir tujuh abad, dan paling lama adalah pada zaman Edo (1603-1867). Pada zaman Edo, para samurai (bushi) tidak lagi sering melakukan peperangan seperti pada masa-masa sebelumnya. Pemerintahan Tokugawa berhasil menciptakan kondisi negara yang lebih damai daripada pada masa sebelumnya. Salah satu cara yang mereka tempuh adalah menerapkan politik sakoku (menutup negeri dari pengaruh bangsa asing), yang salah satu tujuannya adalah membendung pengaruh misionaris agama kristen. Mereka hanya berhubungan dengan Cina, Korea, dan Belanda dengan pengawasan yang sangat ketat dan hanya di pelabuhan Nagasaki, yang dilakukan untuk memenuhi kebutuhan kaum bangsawan, misalnya kain sutra.

Untuk menjaga agar kaum samurai tetap setia kepada penguasa, mereka diwajibkan untuk memelajari ajaran Konfusius yang dianggap dapat membangkitkan kepatuhan dan pengabdian. Pada awalnya konfusianisme yang masuk ke Jepang pada sekitar abad ke-6 hanya dipelajari oleh sebagian kecil masyarakat saja, khususnya kaum bangsawan dan pendeta Buddha. Namun, pada zaman Edo pengaruh konfusianisme semakin meluas; ajaran itu dipelajari kalangan masyarakat umum. Pada perkembangannya lahir dan berkembanglah pola ideal seorang samurai yang kemudian dikenal dengan nama bushido (jalan bushi atau jalan samurai). Hal tersebut merupakan penyatuan prinsip kesetiaan dan keberanian samurai berdasarkan sikap moral ajaran Konfusius yang menjadi pedoman moral bagi samurai, yang bercampur dengan ajaran Buddha beraliran Zen dan Shinto yang sebelumnya sudah ada di Jepang. Zen mengajarkan "harmoni", sedangkan Shinto menekankan kesetiaan kepada negara, dan kaisar atau penguasa. Selain itu, mereka juga menekankan kehormatan dan harga diri.

Jika pada masa sebelum Tokugawa kaum samurai lebih berperan sebagai kekuatan militer, pada era Tokugawa yang relatif damai, tanpa perang antartuan tanah atau daimyo, mereka lebih banyak berperan dalam bidang administrasi dan politik, di samping ada yang tetap sebagai militer. Dengan peranan tersebut, sikap hidup yang mereka anut berpengaruh pada kalangan masyarakat luas dari golongan lainnya.

Yamaga Shoko (1622-1685), seorang ahli konfusianisme, mengatakan bahwa seorang samurai harus memiliki moral yang dapat menegakkan kewibawaannya, seperti pengendalian diri, kesetiaan pada atasan, berkorban demi tugas, dan memiliki sikap sungguh-sungguh (Shoko dalam de Barry 1974: 395). Ia menekankan pentingnya wawasan berpikir yang luas bagi para samurai. Agar dapat lebih bijaksana dalam memerintah, mereka perlu belajar berbagai hal yang tidak ada kaitannya dengan kemiliteran, seperti kesenian, ilmu kemasyarakatan, kesusastraan, dan sejarah. Seorang samurai juga dituntut untuk jujur dan berani, tidak hanya berani dalam peperangan, tetapi juga berani dalam menjalani kehidupan, dan berani menegakkan kebenaran. Pada zaman modern apresiasi dan penghayatan musik dan sajak indah atau karya sastra lainnya masuk dalam kurikulum pendidikan di Jepang. Hal ini dianggap perlu untuk dapat membangkitkan perasaan dan jiwa yang lembut. 
Seseorang dianggap akan menjadi lebih santun dengan memelajari dan memahami hal tersebut. Sikap sopan santun ini memiliki korelasi dengan rasa kasih sayang. Sikap ini adalah unsur kemanusiaan tertinggi dan hasil terbaik dari hubungan kemasyarakatan. Dari sikap menghormati antarsesama, akan muncul tenggang rasa.

Di bawah pemerintahan Tokugawa yang relatif damai tersebut, kelas samurai kehilangan pekerjaannya untuk berperang. Hal itu sangat besar maknanya karena perang diperlukan untuk dijadikan legitimasi status mereka sebagai strata tertinggi dari empat strata sosial yang ada: samurai, petani, perajin, dan pedagang. Keberadaan samurai yang mendapatkan gaji dari tuannya tampak menjadi seperti parasit yang membebani kelas sosial lain, makan makanan dari petani, dan memakai barang dari perajin atau pedagang. Singkatnya, kaum samurai dapat menikmati berbagai kemudahan dan fasilitas. Kumazawa Banzan dan Yamaga Soko berpikir bahwa para samurai mungkin mempunyai suatu fungsi penting yang mencakupi menempuh dinas militer, menjadi pemimpin dan teladan bagi kelas sosial lainnya, misalnya dalam bidang seni, atau memperlihatkan pengabdian dan berkorban demi tugas $(g i)$. Tugas seorang samurai adalah melayani tuannya dengan penuh kesetiaan, dengan meletakkan pengorbanan diri di atas kepentingan pribadi. Meskipun merupakan suatu etika yang tidak tertulis, bushido tertanam lekat dan menyatu dalam diri para samurai, yang diimplementasikan dalam tindakan mereka.

\section{Modernisasi dan Impor KebUdayaAn}

Kata Jepang Modern dalam makalah ini mengacu pada Jepang setelah restorasi Meiji, 1868. Bagaimana dengan bushido pada era Jepang modern? Masih adakah nilai-nilai bushido yang tetap bertahan dan tidak hanyut diterpa gelombang modernisasi yang dahsyat sejak Restorasi Meiji? Untuk menjawab pertanyaan di atas terlebih dahulu perlu dipahami modernisasi Jepang atau Restorasi Meiji (1868).

Modernisasi adalah suatu istilah yang menggambarkan suatu perubahan. Istilah modern akan menghubungkan manusia dengan masa lalu karena adanya proses perubahan dari yang lama ke yang baru. Meskipun demikian, tidak semua perubahan ada hubungannya dengan modernisasi. Kita menyadari proses sosial yang memiliki berbagai aspek dalam masyarakat merupakan tempat pola-pola produksi baru, model baru dalam hubungan antarmanusia, dan pola sosial yang baru diadopsi. Bradbury (1971) menyatakan bahwa dengan perubahan yang terus-menerus, dunia modern menjadi serba tidak tetap, serba tidak pasti, tidak ada yang mutlak, dan juga penuh keanekaragaman. Terlepas dari segala aspek dalam modernisasi, tidak dapat dimungkiri bahwa kita semua terlibat, baik sebagai pelaku modernisasi maupun hanya sebagai korban modernisasi.

Istilah modernisasi Jepang biasanya mengacu pada Meiji ishin, atau Restorasi Meiji tahun 1868. Jepang yang sebelumnya menerapkan politik menutup negeri dari pengaruh asing (sakoku) selama sekitar 270 tahun mulai 
membuka diri (kaikoku). Ini merupakan sebuah titik balik yang sangat penting dalam sejarah Jepang. Secara langsung peristiwa ini dipicu oleh tekanan Amerika Serikat yang mengirim Komodor Perry dengan empat buah kapal perang di tahun 1853. Dengan demikian, dimulailah modernisasi Jepang secara besar-besaran. Pada mulanya Meiji ishin merupakan pembaruan di bidang politik dan industri, yang kemudian berkembang ke segenap aspek kehidupan. Karena Jepang banyak meniru, atau mengadopsi banyak hal dari Barat, tidak sedikit pula yang mengatakan modernisasi Jepang sebagai westernisasi atau pembaratan. Hal ini dilakukan karena Jepang menyadari ketertinggalan mereka dari Barat, khususnya dalam ilmu pengetahuan dan teknologi, sehingga berusaha mengejar ketertinggalan tersebut. Hal ini mereka lakukan, misalnya, untuk menghindari agresi negara Barat. Restorasi Meiji ini tidak terlepas dari pengaruh revolusi yang terjadi di Prancis dan Inggris, yang kemudian berkembang ke seluruh dunia. Arus modernisasi yang bermula dari kedua revolusi ini pun akhirnya melanda Jepang. Tampak juga antusiasme Jepang terhadap kebudayaan Barat. Perubahan besar terjadi di hampir segala bidang, seperti penghapusan hak-hak istimewa kaum militer, penghapusan pembatasan mengenai pekerjaan, dan pendidikan. Jepang benar-benar mengalami suatu perubahan yang luar biasa dalam waktu yang singkat pada era Meiji ini.

Restorasi Meiji secara tidak langsung dipengaruhi oleh keadaan dunia pada saat itu, yaitu adanya perebutan pasar untuk menjual hasil industri di antara negara-negara Eropa sebagai dampak dari Revolusi Industri yang bermula di Inggris. Dari segi politis, Restorasi Meiji merupakan gerakan yang mengakhiri dominasi yang sangat lama dari kelas samurai (bushi) Shogun Tokugawa. Tujuan dari restorasi ini adalah menerapkan modernisasi cara Barat di Jepang. Jepang menyadari ketinggalan mereka, dan berusaha secepatnya mengejar ketertinggalan tersebut, yaitu secara besar-besaran mengimpor dan melaksanakan modernisasi di berbagai bidang, yakni ekonomi, kebudayaan, politik, pendidikan, dan kemiliteran. Ke luar, ideologi

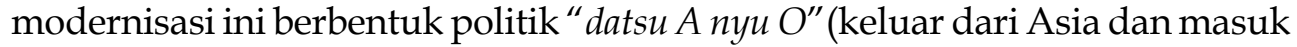
ke Eropa), sementara ke dalam mereka menerapkan politik "Wakon Yosai" (kepribadian Jepang, teknologi Barat). Ideologi Wakon ini merupakan salah satu cara Jepang untuk menghadapi derasnya pengaruh kebudayaan Barat pasca-Restorasi Meiji dengan tetap melestarikan nilai-nilai tradisional yang telah lama ada. Salah satunya adalah nilai-nilai bushido.

Walaupun demikian, bukan berarti bahwa proses Restorasi Meiji seluruhnya berjalan lancar. Tidak sedikit yang merasa bingung dengan kondisi Jepang yang mengalami perubahan demikian drastis. Sikap setuju dan tidak setuju terus bergulir dalam masa transisi ini. Banyak juga yang mengkhawatirkan kebudayaan mereka sendiri. Di kalangan cendekiawan pun terjadi berbagai macam polemik. Setidaknya ada dua kubu yang saling bertentangan, yaitu Minyusha dan Seikyosha. Di satu pihak kelompok Minyusha, yang diketuai Tokutomi Soho, menyetujui impor kebudayaan Barat, dengan alasan agar Jepang dapat mengejar ketertinggalannya dari Barat. Di pihak 
lain, kelompok Seikyosha yang dipimpin oleh Miyake Setsurei bertujuan tetap melestarikan kebudayaan Jepang (Shively 1971: 77). Banyak yang menilai bahwa perubahan yang terjadi terlalu ekstrem sehingga memunculkan berbagai kekhawatiran. Pemerintah tampaknya menyadari hal ini sehingga pengaruh asing yang ada dalam buku teks sekolah dikurangi dan nasionalisme mulai ditanamkan dalam masyarakat.

Kelompok kaikoku-ha (propembukaan negara) berpendapat bahwa diperlukan unsur kebudayaan asing untuk mencapai tujuan negara yang kaya dengan militer yang kuat (fukoku kyohei) yang menjadi semboyan yang dikumandangkan pada masa Meiji. Adapun kelompok yang menentang (joiha) berpendapat bahwa masuknya unsur kebudayaan asing akan merusak tatanan masyarakat yang ada karena tidak sesuai dengan etika Konfusius yang selama ini dianut. Meskipun demikian, ada kelompok lain yang dipelopori Sakuma Shozan yang berpendapat bahwa untuk mengejar ketinggalannya dari Barat, Jepang tidak bisa hanya berkiblat pada Barat saja. Hal ini memunculkan konsep manusia ideal, yakni wakon yosai, yang berarti berjiwa Jepang dan menguasai ilmu pengetahuan Barat. Dengan demikian, untuk menjadi modern tidak harus meninggalkan etika ketimuran, yang dalam hal ini adalah etika Konfusius yang selama ini dianut mereka. Jika dilihat secara menyeluruh, hal itu tidak pula terlepas dari semangat nasionalisme yang menjadi perekat dalam mancapai tujuan bersama.

Demikianlah dengan Meiji ishin pemerintah Jepang berusaha mengejar ketinggalannya dari Barat dengan membangun Jepang "secara Barat". Hal ini berarti, untuk mengejar ketertinggalannya dari Barat, Jepang meniru dan mengadopsi barbagai hal dari Barat, mulai dari sistem pendidikan, hukum, ekonomi, hingga teknologi.

\section{SEPPUKU}

Pada awal Meiji, loyalitas kepada shogun digantikan oleh loyalitas kepada negara dan kaisar. Masalah loyalitas yang merupakan bagian dari nilai-nilai bushido ini dapat dijumpai dalam karya sastra pasca-Restorasi Meiji. Misalnya, dalam Sakai Jiken karya Mori Ogai dengan jelas dapat dilihat pengorbanan diri demi negara dengan melakukan seppuku atau harakiri (bunuh diri dengan memotong perut). Dalam karya tersebut diceritakan bahwa pada tahun 1868 pasukan Angkatan Laut Prancis mendarat di pelabuhan Sakai, dan terjadi pertempuran karena kesalahpahaman antara pasukan Prancis dan Jepang. Sejumlah dua puluh orang anggota pasukan Jepang diperintahkan melakukan seppuku oleh pemerintah karena mereka telah membunuh anggota pasukan Prancis sehingga membuat mereka marah pada saat Jepang harus membina hubungan baik dengan negara-negara asing. Karena seppuku hanya diperuntukkan bagi kaum samurai, kedua puluh orang tersebut haruslah samurai. Mereka sangat gembira pada saat menerima kain sutra dan minuman sake dan diangkat menjadi samurai dadakan. Di sepanjang perjalanan menuju kuil tempat mereka akan melakukan seppuku, banyak orang yang merasa kasihan. Sebelas dari dua puluh orang tersebut akhirnya meninggal, 
sedangkan sisanya mendapatkan ampunan atas permintaan pihak Prancis yang tidak tega melihat seppuku. Karya seperti ini cukup banyak menghiasi ranah kesustraan Jepang modern.

Sikap pemerintah dan masyarakat terhadap para anggota pasukan Jepang yang mati untuk negaranya perlu mendapat perhatian. Mereka diperlakukan bukan sebagai penjahat, melainkan sebagai pahlawan. Oleh karena itu, hingga saat ini kunjungan ke Kuil Yasukuni, tempat dimakamkan banyak tentara Jepang korban perang tetap dilakukan oleh anggota parlemen dan perdana menteri Jepang meskipun mendapat kecaman dari berbagai negara, khususnya Korea dan Cina, karena tempat tersebut dianggap sebagai tempat pemakaman penjahat perang.

Rasa tanggung jawab atas tugas yang diemban dapat dilihat dalam karya Ogai yang lain, misalnya Okitsu Yagoemon no Isho. Karya ini diinspirasi oleh peristiwa bunuh dirinya Jenderal Nogi yang gagal mempertahankan panji-panji yang dipercayakan kaisar pada dirinya. Setelah Kaisar Meiji wafat, Jenderal Nogi pun ikut menyusul mati dengan cara bunuh diri untuk menunjukkan kesetiaannya kepada kaisar Meiji. Bunuh diri untuk menunjukkan kesetiaan ini disebut dengan junshi. Masyarakat Jepang dewasa ini sepertinya masih berusaha memelihara nilai-nilai moral tradisional seperti ini dengan berbagai cara, yang tentu saja berbeda dengan yang dilakukan para samurai.

Pada tahun 1970 sastrawan terkemuka Mishima Yukio dan seorang temannya melakukan tindakan seppuku di depan umum yang sangat menggemparkan di kantor pusat pasukan bela diri Jepang. Pada tahun 1999 seorang karyawan Bridgestone, Nonaka Masaharu (58 tahun) melakukan tindakan seppuku dengan menggunakan pisau sashimi untuk memprotes pemecatan dirinya. Tindakannya tersebut oleh media massa Jepang sering disebut sebagai risutora seppuku, atau seppuku karena pemutusan hubungan kerja, yang juga disebut sebagai simbol kepudaran bubble ekonomi di Jepang.

Banyak hal yang menyebabkan penyisaan "etika lama" dalam masyarakat Jepang dewasa ini. Jika diperhatikan, orang Jepang sangat serius dan teliti dalam memperkenalkan tata krama dan moral pada anak didik dalam mempraktikkan perilaku sosial yang baik. Misalnya saja cara membungkuk dan duduk yang benar. Perilaku itu kemudian melembaga, seperti yang tegas terlihat dalam upacara minum teh (chanoyu). Pada hakikatnya chanoyu mengajarkan orang untuk bersikap sopan, saling menghormati, terkendali, sesuai dengan tata krama, sehingga tercipta suatu ketenangan dan rasa kebersamaan. Rasa kebersamaan ini dianggap sangat penting dalam masyarakat Jepang. Akibatnya, mereka terkotak-kotak dalam kelompok, yang tentu saja memiliki kepentingan, ciri khas, dan aturan tersendiri.

Tentu saja setiap suku bangsa ataupun negara memiliki etika dan sopan santun yang berbeda. Misalnya saja di negara Barat, jika seseorang memberikan hadiah, ia akan memuji-muji pemberiannya kepada orang yang diberi, sebagai bentuk penghargaan kepadanya yang memberikan sesuatu yang baik. Sebaliknya, di Jepang si pemberi akan merendahkan nilai 
hadiahnya di hadapan orang yang diberinya dengan mengatakan tsumaranai mono desuga yang dapat diartikan sebagai barang yang tidak berharga. Orang Jepang sepertinya lebih menekankan nilai spiritual atau perhatian yang ingin diungkapkannya melalui hadiah tersebut. Sikap seperti ini juga tampak pada para pegulat sumo yang tidak memperlihatkan ekspresi emosi berlebihan, baik ketika menang maupun kalah. Hal ini sangat berbeda dengan olahraga lain. Ini dapat saja dikaitkan dengan etika samurai yang harus berani, namun tetap rendah hati. Para samurai yang melakukan harakiri atau seppuku pun melakukannya dengan wajah tetap tersenyum.

Harga diri dan kehormatan merupakan hal yang penting bagi seorang samurai. Mancius, yang dikutip oleh Nitobe (1974), mengatakan bahwa rasa malu adalah lahan dari segala kebajikan, tempat tumbuh pepohonan kelakuan baik dan moral yang baik. Karena itu, seorang samurai merasa lebih baik mati daripada menanggung malu. Untuk mengimbangi hal tersebut, seorang samurai juga belajar mengenai kesabaran dan kemurahan hati. Dalam kasus seorang pengusaha atau direktur yang bunuh diri, sebenarnya sangat sulit menentukan atau menilai mana yang lebih dominan antara sebagai bentuk dari rasa tanggung jawab ataukah karena takut menanggung malu. Sebagaimana sudah disebutkan di atas, orang Jepang sangat terikat pada kelompok sehingga, jika kelompok tersebut tidak dapat menerimanya, yang bersangkutan akan kehilangan pegangan.

Dengan etika bushido, Jepang mampu melewati masa peralihan yang sangat penting, termasuk era Meiji. Dengan Restorasi Meiji, walaupun pemerintah feodal runtuh dan digantikan dengan pemerintahan baru yang lebih demokratis, bushido yang merupakan peninggalan lama masih tetap berpengaruh pada pembentukan aturan baru tersebut. Semangat bushido bukan berarti lenyap bersamaan dengan dihapuskannya sistem stratifikasi sosial pada masa Meiji. Dengan adanya etika tersebut, pengaruh Barat yang masuk dengan derasnya pada masa Meiji tidak menghancurkan karakteristik asli bangsa Jepang. Walaupun kaum samurai memiliki posisi tersendiri yang berbeda dengan rakyat kebanyakan, perilaku dan nilai-nilai yang mereka junjung tinggi pada akhirnya diikuti dan menjadi pedoman, serta mengakar pada masyarakat luas. Hal ini juga terlihat pada karya sastra yang tidak sedikit mengambil tema kehidupan kaum samurai, seperti karya Mori Ogai yang sudah dibicarakan di atas.

Selama Restorasi Meiji terlihat bahwa kelak tidak akan ada lagi tempat bagi kelas samurai. Jepang bergerak cepat menuju modernisasi dan tidak menyediakan banyak tempat bagi kebanyakan samurai. Bagaimanapun, meskipun Jepang melakukan pembaruan besar-besaran, satu hal yang tetap tinggal adalah pentingnya kehormatan dan keberanian. Semangat bushido, meskipun pada awalnya diterapkan oleh para samurai, diadopsi oleh Jepang modern dan diterapkan pada berbagai aspek kehidupan dan masih tersisa hingga saat ini. Sikap berani, termasuk berani berkorban dan yang ditambah loyalitas, menjadikan Jepang mampu mengatasi ketertinggalannya dari Barat. Tidak sedikit yang beranggapan bahwa para pekerja Jepang mengorbankan 
segalanya, termasuk keluarganya, demi perusahaan. Sebagai dampaknya peranan ayah sebagai pemimpin keluarga menjadi berkurang, dan pendidikan anak dilakukan oleh ibu (kyoiku mama) sehingga terkadang ayah menjadi kurang dihargai akibat jarang di rumah dan kurang berkomunikasi dengan anaknya.

Restorasi Meiji menjadikan Jepang negara kuat, dan dalam Perang Dunia II posisi Jepang menjadi lebih kuat lagi. Selama periode ini terdapat pilot-pilot pesawat tempur dalam sebuah skuadron yang dikenal dengan Kamikaze, yang berarti 'Angin Dewa'. Para pilot ini menjadi harapan satu-satunya ketika mereka menderita kekalahan atau terdesak dalam peperangan. Kamikaze adalah para pilot yang memperlihatkan loyalitas dengan bersedia mati demi tugas sebagaimana para samurai yang menjadi inspirasi mereka. Dewasa ini pun, semangat tersebut muncul dalam bentuk, misalnya, bahwa orang Jepang rata-rata masih sangat menghargai atasan mereka: sejumlah pebisnis mundur dari jabatan atau bahkan bunuh diri ketika dipecat atau melakukan kesalahan fatal. Itu merupakan salah satu bentuk dari nilai bushido yang masih tersisa. Meskipun hal tersebut belum tentu melulu karena rasa tanggung jawab, bisa saja karena merasa malu atau karena diliputi bayang-bayang gelap karena sulit diterima oleh lingkungan atau kelompok tempat ia berada.

Setelah Perang Dunia II, angkatan perang Jepang dipisah-pisah dan Jepang menggeser visi mereka ke dunia usaha. Landasan berpikir orang Jepang sebagaimana bara samurai masih ada yang dapat dilihat di perusahaan, yakni dengan pembentukan perusahaan besar yang disebut zaibatsu, yang mempekerjakan para pekerja seumur hidup. Karena itu, para pekerja ini dituntut loyal pada tempatnya bekerja karena tidak mudah untuk alih pekerjaan. Meskipun demikian, akhir-akhir ini kecenderungan ini mulai berubah, seiring dengan semakin meningkatnya jumlah orang, khusunya kaum muda yang memilih bekerja paruh waktu.

Hubungan perusahaan dan para pekerja lebih seperti hubungan keluarga daripada seperti hubungan budak dan majikan. Perusahaan ini menuntut kesetiaan yang serupa dengan para samurai di masa lampau. Nilai-nilai zen dari samurai dikenal baik oleh para pekerja ini, mereka loyal dan dituntut untuk mau berkorban untuk perusahaan mereka.

Pada zaman modern ini, di Jepang samurai diangkat kembali dengan rasa hormat dan dihargai seperti pahlawan. Dengan mudah kita bisa mendapati karya sastra dan film yang berkisah tentang sepak terjang kelas prajurit ini. Contoh yang paling terkenal adalah film produksi tahun 1954 Tujuh Samurai (Shichinin no Samurai) arahan sutradara besar Kurosawa Akira. Bahkan, film animasi yang pernah sangat populer Sailor Moon dikatakan mempunyai unsur-unsur pengaruh dari samurai. Ini hanya sedikit contoh dari kebudayaan populer Jepang yang memperkenalkan samurai atau etika bushido kepada dunia, dan memelihara legenda Jepang agar tetap hidup. Masih banyak lagi contoh lain yang dapat dijumpai, misalnya pada komik, dan video game.

Dewasa ini, ketika tidak ada kelas samurai, bushido tidak lagi mempunyai kekuatan militer. Namun, bagaimanapun, dasar etika bushido masih 
memainkan peranan dalam kebudayaan dan masyarakat Jepang. Penekanan Bushido pada loyalitas pada atasan sebuah kelompok masih jelas terlihat pada loyalitas para pekerja pada pekerjaan mereka, para siswa kepada guru, atau individu yang bekerja atau bertindak dengan bermuara bagi kepentingan negara. Semangat atau etika bushido yang tersisa pada masa kini tentu saja berbeda dengan para samurai yang memilih mati dengan cara terhormat demi membela tuannya atau demi kehormatan. Perwujudan lebih pada nilai-nilai yang terkandung di dalamnya, seperti bekerja keras, menghormati atasan atau yang lebih senior, loyalitas, dan sebagainya. Sistem nenkojoretsu (senioritas) yang ada dalam perusaahan Jepang juga merupakan salah satu bentuk dari etika tersebut.

Etika, semangat, ataupun ajaran moral diajarkan kepada murid-murid sekolah di Jepang melalui pelajaran moral (doutoku), termasuk di dalamnya adalah unsur kesetiaan. Hal ini dilakukan untuk memupuk moral sejak dini. Namun, etika moral tradisional yang selama ini dianggap melekat dalam diri bangsa Jepang tampak semakin memudar. Hal ini dapat dilihat pada gaya hidup dan perilaku kaum muda Jepang dewasa ini yang menimbulkan kekhawatiran generasi sebelumnya, khusunya yang mengalami masa-masa sulit, seperti Perang Dunia Ke-2.

Munculnya fenomena NEET, hikikomori, meningkatnya angka kenakalan remaja, bertambahnya minat bekerja paruh waktu, dan sebagainya menjadi kekhawatiran dan pembicaraan luas dalam masyarakat Jepang dewasa ini. NEET atau biasanya dilafalkan sebagai niito merupakan singkatan dari not in employment, education, or training, atau orang yang tidak mau sekolah ataupun bekerja, sekali pun kerja paruh waktu. Adapun hikikomori adalah orang yang mengurung diri di kamar, tidak bekerja dan tidak mempunyai pergaulan sosial sama sekali. Para pemuda dewasa ini sering dianggap apatis terhadap berbagai permasalahan yang muncul dalam masyarakat.

Hal di atas sangat erat hubungannya dengan berkurangnya rasa tanggung jawab sosial, yang berujung pada tanggung jawab pada negara. Sementara itu, Jepang pun dililit oleh berbagai permasalahan, seperti berkurangnya angka kelahiran (shoshika) dan melajunya angka lansia (koreika), yang menuntut peran serta semua anggota masyarakat dan keseriusan penanganan pemerintah.

\section{Penutur}

Bangsa yang memiliki keinginan untuk maju haruslah mau belajar, baik dari bangsa lain maupun dari apa yang mereka alami. Keinginan untuk berbuat sesuatu yang baik dengan semangat tinggi untuk kepentingan negara merupakan modal yang sangat penting. Hal ini dapat dicapai dengan kerja keras, menjaga kehormatan, jujur, dan bertanggung jawab. Modal inilah yang dimiliki bangsa Jepang pada saat mereka menyadari ketertinggalan mereka dari bangsa Barat. Mereka berusaha mengejarnya dan, dengan memanfaatkan momentum penting, mampu menjadi negara modern tanpa harus meninggalkan tradisi yang mereka miliki. Bahkan, mereka mampu memadukan, atau justru memanfaatkannya dengan baik. Tentu saja etos 
atau semangat yang mereka miliki tersebut bukan suatu hal yang muncul begitu saja, melainkan suatu warisan yang terus dipupuk, dilestarikan, dan dimanfaatkan dengan baik.

Berbagai masalah yang muncul dalam masyarakat Jepang dewasa ini, seperti fenomena NEET dan hikikomori, sangat menarik untuk dicermati dan diteliti lebih jauh, apakah ada kaitannya dengan pemudaran atau pergeseran nilai-nilai tradisional, seperti bushido, ataukah karena penyebab lainnya. Selain itu, mungkin saja hal di atas berpengaruh pada penurunan perekonomian Jepang. Hal itu dapat saja karena bergeser orientasi pendidikan yang sangat menekankan pada bidang teknologi dan ekonomi. Karya sastra baru yang berkaitan dengan etika bushido, misalnya, juga sudah semakin sulit ditemukan.

Tentu saja dalam suatu perubahan, tidak semua orang atau anggota masyarakat dapat mengikui atau menyesuaikan diri. Orang-orang yang tidak mampu mengikutinya akan tergilas dan menjadi korban perubahan yang terjadi.

\section{DAFTAR ACUAN}

Bary, Wm. Theodore de (ed.) (1964), Sources of Japanese Tradition. Vol. II. New York: Columbia University Press.

Black, C.E. (1967), The Dynamics of Modernization, A Study Comparative History. New York: Harper Torchbook.

Bowring, Richard John (1979), Mori Ogai and The Modernization of Japanese Culture. Cambridge: Cambridge University Press.

Bradbury, Malcolm (1971), The Social Context of Modern English Literature. Oxford: Basil Blakcwell.

De Bary, Wm. Theodeore (ed.) (1974), Sources of Japanese Traditional. New York: Colombia University Press.

Draeger, D.F. (1979), Classical Budo: The Martial Arts and Ways of Japan: Volume II. New York, NY: John Weatherhill, Inc.

Fewster, Stuart dan Gorton (1988), Japan: From Shogun to Superstate. Woodchurch: Paul Norbury Publications.

Harrison, E. J. (1982), The Fighting Spirit of Japan. Woodstock, NY: The Overlook Press.

Irokawa Daikichi (1985), The Culture of Meiji Periode. Princeton: Princeton University Press.

Jansen, Marius B, (ed.) (1972), Changing Japanese Attitude Toward Modernization. Princeton: Princeton University Press.

Kosaka, Masaki (1969), Japanese Thought in The Meiji Era. Tokyo: The Toyo Bunko.

Minami Hiroshi (1993), Nihonteki Jiga. Tokyo: Iwanami Shinsho.

Nakamura Fumio (I992), Mori Ogai to Meiji Kokka. Tokyo: Sanichi Shobo.

Newman, J. (1989), Bushido: The Way of the Warrior. Leicester, UK: Magna Books.

Nitobe Inazo (1974), Bushido, The Soul of Japan. Tokyo: Charles E. Tuttle.

_ (2003), Bushido - Ima, Yotte Tasubeki "Nihon no Seishin". Tokyo: PHP Editors Group.

Pyle, Kenneth B. (1988), Generasi Baru Zaman Meiji: Pergolakan Mencari Identitas Nasional. Terjemahan Arifin Bey. Jakarta: PT Gramedia.

Sato Masahiro (2001), Nihon no Kokoro to "Bushido". Tokyo: Kyobunkan.

Shively, Donald H. (ed.) (1971), Tradition and Modernization in Japanese Culture. Princeton: Princeton University Press.

Stuart, Fewster dan Gorton (1988), Japan: From Shogun to Superstate, Woodchurch: Paul Norbury Publications. 
Varley, H. Paul. (1971), Imperial Restoration in Medieval Japan, Columbia U.P. Yuasa, Yasuo (1967), Keizai jin no Moral. Tokyo: Doko Shinsho.

Yamamoto Hirofumi (2003), Bushi to Seken-Naze Shi ni Isogunoka. Tokyo: Chuko Shinsho. 